\title{
Spatial and Temporal Distribution of Dissolved Oxygen and Suspended Sediment in Kelantan River Basin
}

\author{
Arniza Fitri ${ }^{1 *}$, Khairul Nizam Abdul Maulud ${ }^{2}$, Farli Rossi ${ }^{1}$, Fajar Dewantoro ${ }^{1}$, Puji \\ Harsanto $^{3}$, Nur Zukrina Zuhairi
}

${ }^{1}$ Universitas Teknokrat Indonesia, Indonesia

${ }^{2}$ Universiti Kebangsaan Malaysia, Malaysia

${ }^{3}$ Universitas Muhammadiyah Yogyakarta, Indonesia

*Corresponding author. Email: arniza@teknokrat.ac.id

\begin{abstract}
Dissolved oxygen and suspended sediment are the most important parameters used to assess the water quality of the river. The concern of freshwater pollution problems in Malaysia since the past few decades has resulted in the importance of monitoring dissolved oxygen concentration as a barometer for river health. This study attempted to identify the spatial and temporal distribution of dissolved oxygen and suspended sediment in the Kelantan River Basin, Peninsular Malaysia. Water samples were collected during dry and wet seasons at three sampling stations along the Kelantan River in 2005, 2006, 2010, 2011, 2017, and 2018. Results showed that the dissolved oxygen in 2005 has ranged between 6.8 and $8.4 \mathrm{mg} / \mathrm{L}$ during the dry season, and there was a slight reduction of DO concentration during the wet season with a concentration between 6.3 and $7.8 \mathrm{mg} / \mathrm{L}$. Continuous declination of DO concentrations was recorded along the Kelantan River from the year 2005 to the year 2018. The decrease of DO concentrations was linear to the increase of suspended sediment concentration. Increasing land use activities for agriculture, mining, and forest harvesting have attributed to the water pollutions in Kelantan River, Malaysia, due to the increase of suspended sediment concentration, which brings the pollutants.
\end{abstract}

Keywords—dissolved oxygen, suspended sediment, pollution, Kelantan River

\section{INTRODUCTION}

Dissolved oxygen is the most important parameter in assessing the water quality for freshwater because it is a key factor for aquatic life [1-3]. The changes of dissolved oxygen concentration in the freshwater can affect the biological and chemical processes in the water body [4]. In addition, suspended sediment is also one of the water quality parameters based on National Water Quality Standard (NWQS) and this parameter is highly recommended to be considered by US APA [5]. It is because suspended sediment can transport and bring the pollutants in aquatic environment [5-7].

Previous studies done by researches in Malaysia have demonstrated that several rivers in Malaysia have been contaminated with pollutions conveying from industrial and domestic wastes as well as agricultural and land use runoff along the river [8-11]. The issues of freshwater pollutions in Malaysia since the past few decades have caused the great concern related to the future scarcity of clean freshwater and therefore it makes the importance of monitoring dissolved oxygen concentration as a barometer for river health [12-16].

This study attempted to present the spatial and temporal distribution of dissolved oxygen and suspended sediment along the Kelantan River Basin, Peninsular Malaysia. The monitoring program of river's dissolved oxygen and suspended sediment is becoming compulsory in order to protect the valuable freshwater resources.

\section{MATERIAL AND METHOD}

\subsection{Location of the Study and the Water Sampling}

The study area was located in the Kelantan River Basin, Malaysia. The water sampling was recorded from three sampling stations/points. Fig. 1 shows the location of the study area and water sampling stations while Table I presents the coordinate of the water sampling stations.

Table I. Coordinate of Water Sampling Stations

\begin{tabular}{|c|c|c|}
\hline Stations & \multicolumn{2}{|c|}{ Coordinate } \\
\hline $\mathrm{K} 1$ & $\mathrm{E} 102^{\circ} 11^{\prime} 43.2^{\prime \prime}$ & $\mathrm{N} 5^{\circ} 32^{\prime} 04.1^{\prime \prime}$ \\
\hline $\mathrm{K} 2$ & $\mathrm{E} 102^{\circ} 09^{\prime} 56.4^{\prime \prime}$ & $\mathrm{N} 5^{\circ} 46^{\prime} 45.3^{\prime \prime}$ \\
\hline $\mathrm{K} 3$ & $\mathrm{E} 102^{\circ} 14^{\prime} 42.0^{\prime}$, & $\mathrm{N} 6^{\circ} 10^{\prime} 19.3^{\prime \prime}$ \\
\hline
\end{tabular}




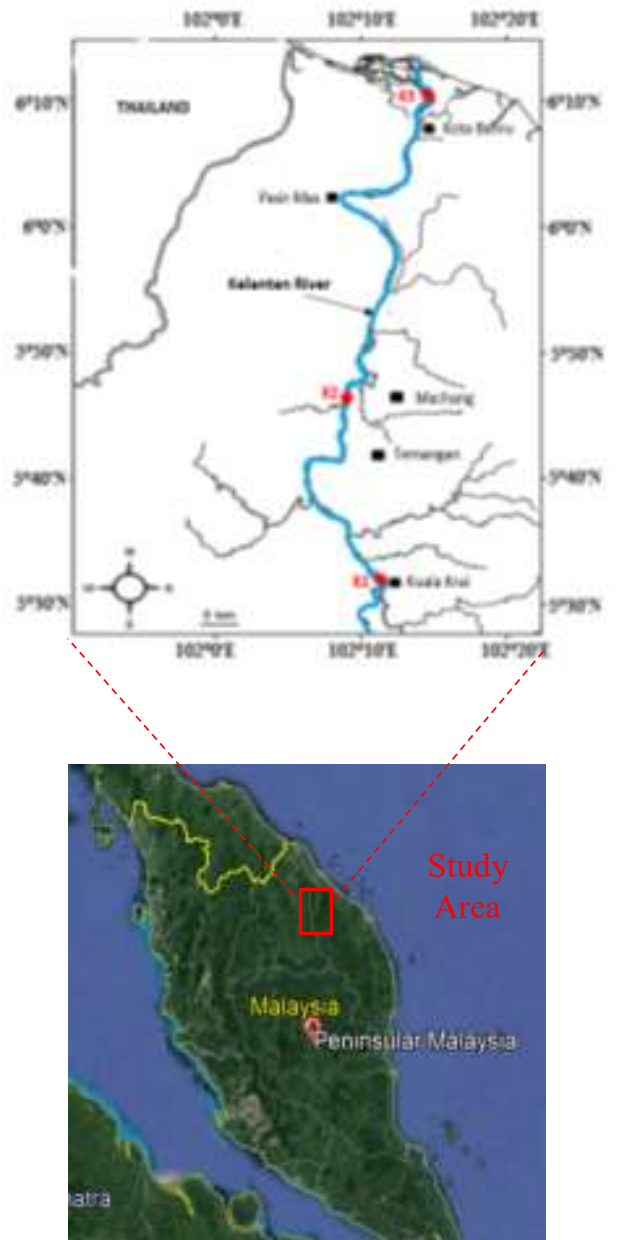

Fig. 1. Description of the study area and location of sampling stations

\subsection{Water Sampling Analyses}

In this study, three water samples were collected from each sampling station during the dry season (August 2005, August 2010 and August 2017) and wet season (January 2006, January 2011 and January 2018). Dissolved oxygen (DO) concentrations were recorded directly in situ by using a YSI meter while TSS were examined in the laboratory according to the APHA method. About $100 \mathrm{ml}$ of each water sample was filtered through filter paper and then, the filter paper was further dried at $105^{\circ} \mathrm{C}$ in an oven. Finally, the dried filter paper was weighted. The TSS concentration was determined by subtracting the weight of dried filter paper containing suspended sediment with clean dried filter paper.

\section{RESULT AND DISCUSSION}

Fig. 2 and Fig. 3 present the distributions of dissolved oxygen and suspended sediments from three water sampling stations between year 2005 and 2018. The presented values of the dissolved oxygen and suspended sediment concentration per each sampling station was the mean values obtained from three water samplings.

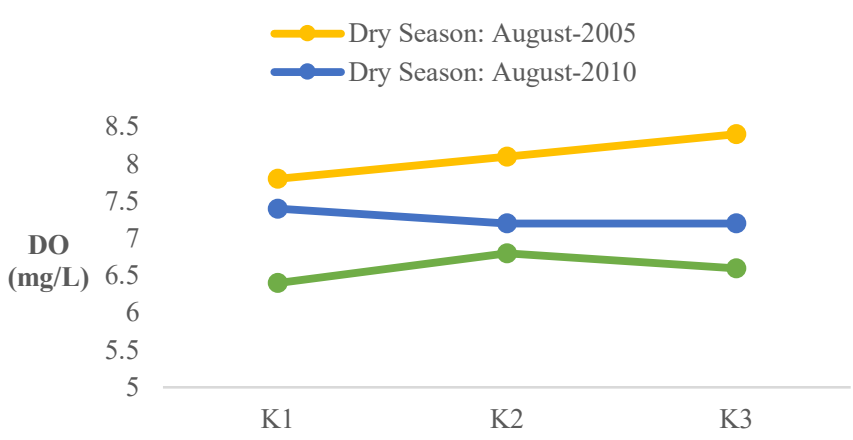

(a) During dry season

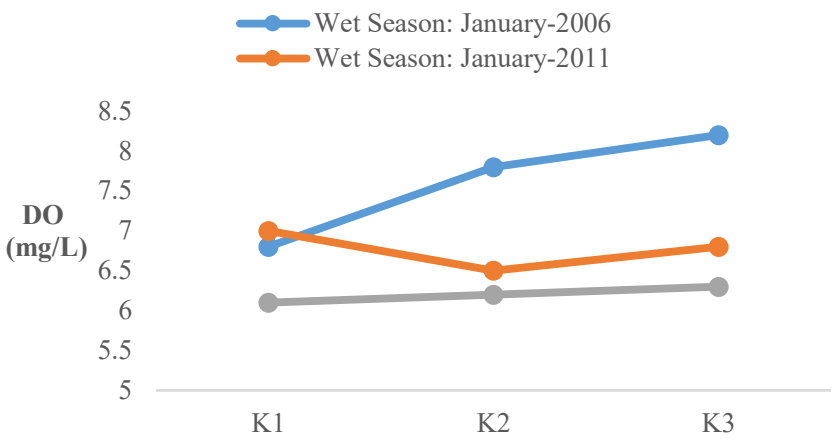

(b) During wet season

Fig. 2. Distribution of dissolved oxigen between 2005 and 2018, (a) during dry season, (b) during wet season

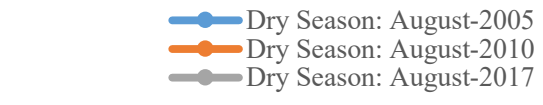

400

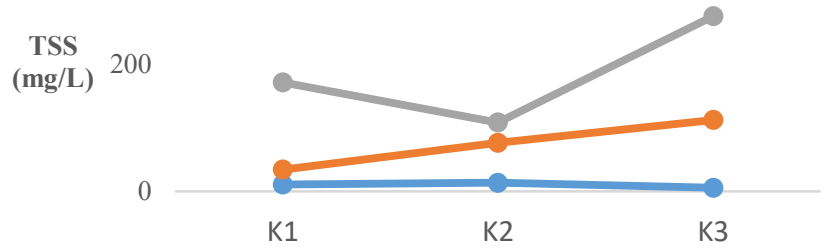

(a) During dry season

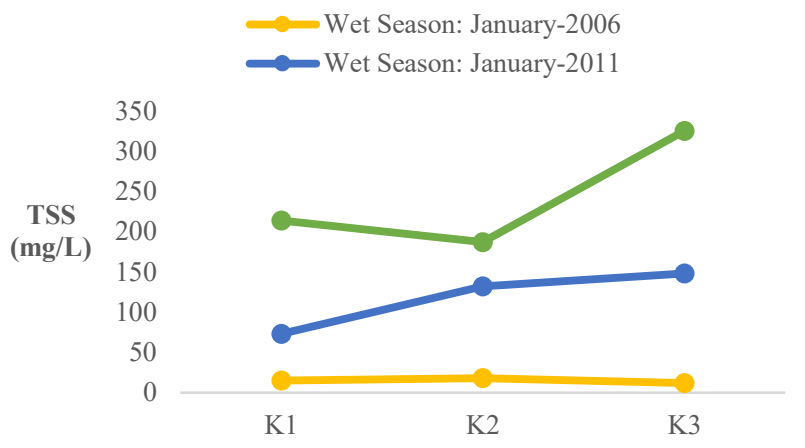

(b) During wet season

Fig. 3. Distribution of suspended sediment between 2005 and 2018, (a) during dry season, (b) during wet season 
Results showed that the concentration of dissolved oxygen in the year 2005 was ranged between 7.8 and $8.4 \mathrm{mg} / \mathrm{L}$ during the dry season, and there was a slight reduction of dissolved oxygen concentration during the wet season with a concentration between 6.8 and $8 \mathrm{mg} / \mathrm{L}$ in 2006 (Fig. 2). In 2010 , there was addition of new factories and agricultural activities (oil palm, paddy etc.) around Temangan, Machang and Kota Bahru at the Kelantan state which was possible conveying the sewage water and runoff to the Kelantan River at sampling stations $\mathrm{K} 2$ and $\mathrm{K} 3$. Based on Figure 2, concentration of dissolved oxygen was much reduced at $\mathrm{K} 2$ and K3 stations in 2010 approximately become $7.2 \mathrm{mg} / \mathrm{L}$ during the dry season and between 6.5 and $6.8 \mathrm{mg} / \mathrm{L}$ during the wet season.

In addition, more factories and agricultural activities (especially oil palm) as well as forest harvesting were recorded after 2013, especially in 2017 around Kuala Krai area at the Kelantan state which was possible conveying the runoff to the Kelantan River particularly at sampling stations K1. Table II presents the changes of agricultural activities between 2005 and 2017 [9, 18, 19], while Fig. 4 presents the land use changes before 2005 and after 2013 [9, 17].

Table II. Agricultural Activities In Kelantan State and The Comparison of DO / TSS Concentrations Between 2005 and

\begin{tabular}{|c|c|c|c|}
\hline Year & $\begin{array}{c}\text { Agricultural } \\
\text { Activities }\end{array}$ & DO (mg/L) & TSS (mg/L) \\
\hline 2005 & $10.43 \%$ & $7.8-8.4$ & $6-18$ \\
\hline 2009 & $14.69 \%$ & $6.5-7.2$ & $34-148$ \\
\hline$>2013$ & $20.67 \%$ & $6.1-6.6$ & $171-325$ \\
\hline
\end{tabular}

Sources for agricultural activities: DOE Malaysia $(2005,2009,2013)$

Overall, results demonstrated that the lower concentration of dissolved oxygen was recorded in 2017 and 2018 compared to $2005,2006,2010$ and 2011 . The lowest concentration of dissolved oxygen was recorded during the wet season at the year 2018 (approximately about 6.1 to $6.3 \mathrm{mg} / \mathrm{L}$ ).

Besides, results also showed that the concentration of suspended sediments in 2005 has ranged between 5.6 and $13.57 \mathrm{mg} / \mathrm{L}$ during the dry season, while the higher concentrations of suspended sediments were recorded during the wet season at 2006 with approximately about 11 to 18 mg/L (Fig. 3). In 2010 and 2011, TSS concentrations ranged from 34 to $112 \mathrm{mg} / \mathrm{L}$ during dry season and from 73 to 148 $\mathrm{mg} / \mathrm{L}$ during wet season. The continuous increase in TSS concentrations were recorded from 2005 to 2018 while the highest concentration of suspended sediments was found during the wet season at 2018 which was approximately about 214 to $325 \mathrm{mg} / \mathrm{L}$.

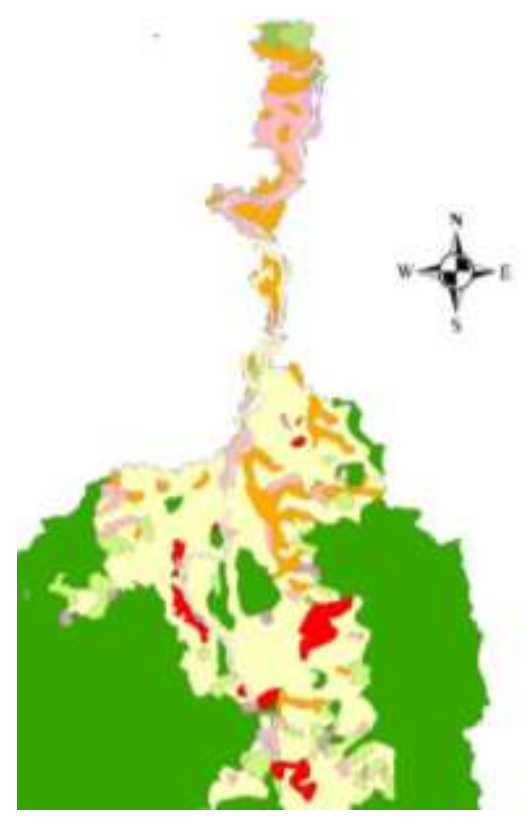

(a) Landuse before 2005

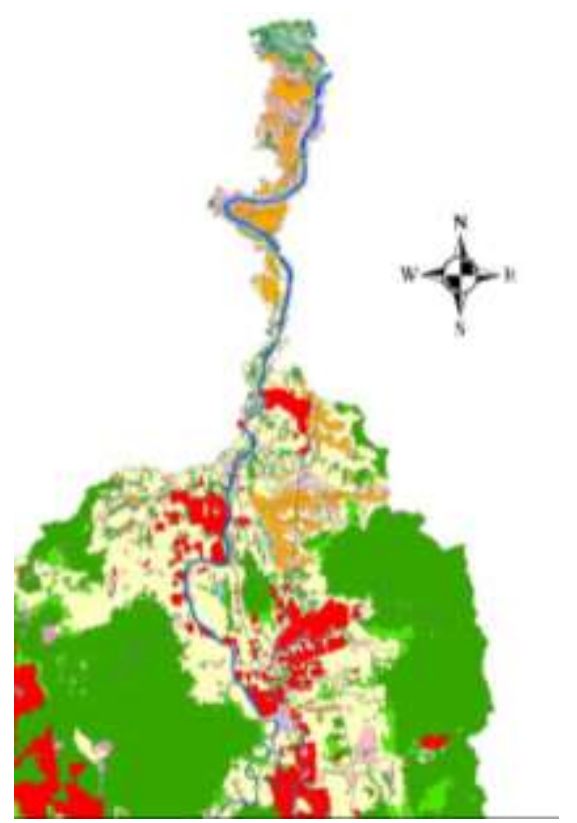

(b) Landuse after 2013

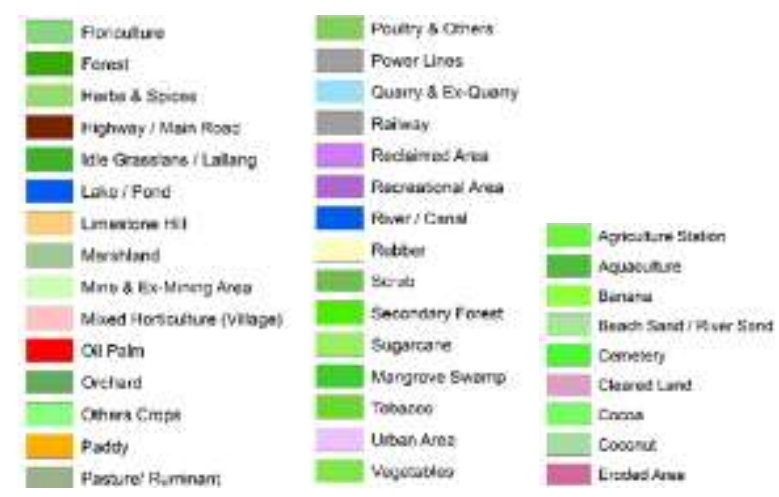

Fig. 4. Landuse changes [9, 17], (a) before 2005, (b) after 2013 
Based on Fig. 2 and Fig. 3, continuous declination of dissolved oxygen concentrations was recorded along the Kelantan River Basin from 2005 to 2018 while in contrast, continuous increase of suspended sediment concentrations were recorded along the Kelantan River Basin from 2005 to 2018. Increasing the number of factories and land use activities for agriculture and forest harvesting have attributed to the increasing of suspended sediment concentration and declining of DO concentration in the Kelantan River.

\section{CONCLUSION}

Dissolved oxygen is the most important parameter used for assessing the status of water quality in freshwater. In this study, the results presented that there was a major declination of dissolved oxygen concentrations in the Kelantan River Basin, Peninsular Malaysia from 2005 to 2018 due to the increase of land use activities in Kelantan State. The decrease of dissolved oxygen concentrations was found to be linear with the increase of suspended sediment concentration. Therefore, the increase of land use activities such as for agriculture, mining, and forest harvesting have attributed to the water pollutions in Kelantan River Basin, Peninsular Malaysia, due to the increase of suspended sediment concentration, which brings the pollutants.

\section{ACKNOWLEDGMENT}

The authors would like to thank Universiti Kebangsaan Malaysia for funding this study (research grant DIP-2018030). The authors also gratefully acknowledge the Earth Observation Centre, Institute of Climate Changes, UKM and Universitas Teknokrat Indonesia for supporting data and spirit to complete this study.

\section{REFERENCES}

[1] N. Naveedullah, M. Z. Hashmi, C. Yu, C. Shen, N Muhammad, H. Shen, and Y. Chen. "Water quality characterization of the siling reservoir (Zhejiang, China) using water quality index," CLEAN-Soil, Air, Water, vol. 44(5), pp. 553-562, 2016

[2] N. A. Wahaba, M. K. A. Kamarudina, M. E. Toriman, H. Juahira, M. H. M. Saada, F. M. Ataa, ... and M. M. Hanafiahd. "Sedimentation and water quality deterioration problems at Terengganu River basin, Terengganu, Malaysia," Desalination and water Treatment, vol. 149, pp. 228-241, 2019.

[3] H. Juahir, S. M. Zain, M. K. Yusoff, T. T. Hanidza, A. M. Armi, M. E. Toriman, and M. Mokhtar. "Spatial water quality assessment of Langat River Basin (Malaysia) using environmetric techniques," Environmental monitoring and assessment, vol. 173(1-4), pp. 625-641, 2011.

[4] V. Z. Antonopoulos, and S. K. Gianniou. "Simulation of water temperature and dissolved oxygen distribution in Lake Vegoritis, Greece," Ecological Modelling, vol. 160(1-2), pp. 39-53, 2003.

[5] A. G. Osman, and W. Kloas. "Water quality and heavy metal monitoring in water, sediments, and tissues of the African
Catfish Clarias gariepinus (Burchell, 1822) from the River Nile, Egypt," Journal of Environmental Protection, vol. 1(04), 389, 2010.

[6] P. R. Kannel, S. Lee, Y. S. Lee, S. R. Kanel, and S. P. Khan. "Application of water quality indices and dissolved oxygen as indicators for river water classification and urban impact assessment," Environmental Monitoring and Assessment, vol. 132 (1-3), pp. 93-110, 2007.

[7] S. H. Lai, and A. Fitri. "Application of SWAT Hydrological Model to Upper Bernam River Basin (UBRB), Malaysia," IUP Journal of Environmental Sciences, vol. 5(2), 2011.

[8] S. Suhaimi, A. Mohamad, A. L. Loh, and M. T. Norhayati. "Kajian Indeks Kualiti Air di Lembangan Sungai Paka, Terengganu," Sains Malaysiana, vol. 38 (2), pp. 125 131, 2009.

[9] DOE. "Malaysia Environmental Quality Report 2013," Department of Environment, Ministry of Science, Technology and Environment Maskha Sdn Bhd, Kuala Lumpur, Malaysia, 2013.

[10] A. Fawaz, O. M. Shuhaimi, and G. M. Barzani. "Water quality assessment of the Semenyih River, Selangor, Malaysia. Journal of Chemistry," pp. 1-10, 2013.

[11] M. Nuraini and K. H. Ang. "Kualiti air Sungai UTM: Satu penilaian awal berpandukan enam parameter Indeks Kualiti Air," Geografia Online Malaysian Journal of Society and Space, vol. 11 (1), pp. 107-115, 2015.

[12] N. A. Wahab, M. K. A. Kamarudin, M. E. Toriman, H. Juahir, M. H. M. Saad, F. M. Ata, A. Ghazali, A. R. Hassan, H. Abdullah, K. N. Maulud, M. M. Hanafiah, H. Harith. "Sedimentation and water quality deterioration problems at Terengganu River basin, Terengganu, Malaysia," Desalination and water Treatment, vol. 149, pp. 28-241, 2019.

[13] M. Kamarudin, A. M. Nalado, M. Toriman, H. Juahir, R. Umar, A. Ismail, N. A. Wahab, M. Saad, K. N. Maulud, M. M. Hanafiah, A. S. Saudi, and H. Harith. "Evolution of river geomorphology to water quality impact using remote sensing and GIS technique," Desalination and Water Treatment, vol. 149, pp. 258-273, 2019.

[14] M. M. Mekonnen, and A. Y. Hoekstra. "Four billion people facing severe water scarcity," Science advances, vol. 2(2), e1500323, 2016

[15] Z. Ujang, R. A. Rahman, and A. N. Anuar. "Current trends in water quality and resources management," In Proceedings of 1st Technical Meeting Muslim Water Researches Cooperation (MUWAREC KL08). Selangor: Universiti Kebangsaan Malaysia, Bangi, December 2008.

[16] L. Y. Heng, L. N. Chukong, R. B. Stuebing, and M. Omar. "The water quality of several oxbow lakes in Sabah, Malaysia and its relation to fish fauna distribution," 2006.

[17] N. Saadatkhah, M. H. Tehrani, S. Mansor, Z. Khuzaimah, A. Kassim, and R. Saadatkhah. "Impact assessment of land cover changes on the runoff changes on the extreme flood events in the Kelantan River basin," Arabian Journal of Geosciences, vol. 9(17), 687, 2016.

[18] DOE. "Malaysia Environmental Quality Report 2005," Department of Environment, Ministry of Science, Technology and Environment Maskha Sdn Bhd, Kuala Lumpur, Malaysia, 2005.

[19] DOE. "Malaysia Environmental Quality Report 2009," Department of Environment, Ministry of Science, Technology and Environment Maskha Sdn Bhd, Kuala Lumpur, Malaysia, 2009. 